\author{
Research Article \\ www.ijrap.net (ISSN:2229-3566)
}

\title{
COMPARATIVE PHYTOCHEMICAL SCREENING OF TWO VALUABLE MEDICINAL PLANTS OF FAMILY APOCYNACEAE (CATHARANTHUS ROSEUS (L.) G.DON. AND ALSTONIA SCHOLARIS (L.) R.BR.)
}

Srushti Prajna Mohanty ${ }^{1}$, Bhaswatimayee Mahakur ${ }^{2}$, Debasis Mitra ${ }^{3}$, Susant Kumar Rout ${ }^{4}$ and Durga Prasad Barik ${ }^{5 *}$

${ }^{1}$ Research Scholar, Department of Botany and Biotechnology, Ravenshaw University, Cuttack, Odisha, India

${ }^{2}$ Project Assistant, Department of Botany and Biotechnology, Ravenshaw University, Cuttack, Odisha, India

${ }^{3}$ Project Assistant, Department of Microbiology, Raiganj University, Raiganj, Uttar Dinajpur, West Bengal, India

${ }^{4}$ Scientist, Science and Technology Department, Government of Odisha, India

${ }^{5}$ Assistant Professor, Department of Botany and Biotechnology, Ravenshaw University, Cuttack, Odisha, India

Received on: 02/03/21 Accepted on: 15/04/21

\author{
*Corresponding author \\ E-mail: dpbarik@ravenshawuniversity.ac.in
}

DOI: $10.7897 / 2277-4343.120243$

\begin{abstract}
Medicinal plants are the significant sources of bioactive compounds worldwide. This study is aimed at qualitative phytochemical screening of leaves constituents of Catharanthus roseus (L.) G. Don. and Alstonia scholaris (L.) R. Br. This analysis of both extracts of plant leaves was done using different solvents such as water, methanol and ethanol using standard methods. The presence of alkaloids, steroids, phenolic compounds, saponins, tannins, terpenoids, flavonoids, cardiac glycosides, anthraquinones, iridoids, carbohydrates, proteins, lipids and vitamins were examined in qualitative study of Catharanthus roseus and Alstonia scholaris. Only ethanol extract contains flavonoids. Steroids are found exclusively in aqueous extracts. This screening gave negative results for the presence of anthraquinones in all the extracts of both the leaves tested. The aqueous extract contains a substantially higher number of phytochemicals in both the leaves'constituents. Extensive study and research on the phytochemical analysis of the plant Catharanthus roseus and Alstonia scholaris will provide wide range information for scientists and researchers regarding apocynaceae family. This can be used to develop new therapies for society's health.
\end{abstract}

Keywords: Alstonia scholaris, Catharanthus roseus, anti-cancer, anti-oxidant, Medicinal plant, Leaf extracts, Phytochemicals

\section{INTRODUCTION}

Plants have been the well-known source of crucial pharmaceuticals of considerable economic importance since time immemorial. More than 50 per cent of the drugs currently used for health care are derived from plants ${ }^{1}$. Medicinal plants do offer enormous possibilities for herbal therapies ${ }^{2}$. Owing to the existence of some phytochemical constituents, these medicinal plants are important in both healing and curing of human diseases $^{3}$. Phytochemicals are biologically active, naturally occurring chemical compounds synthesised in plants. They occur in distinct parts of the plants, for example in underground parts such as roots, stems and in aerial parts such as leaves, buds, fruits or seeds. Many phytochemicals are often found to be concentrated in the outer layers of the many plant tissues, especially the pigment molecules ${ }^{4}$. Medicinal properties are unique to individual plant species or classes and are consistent with the idea that the mixture of secondary products is taxonomically distinct in a particular plant. The emphasis has currently increased when the phytochemical components of a medicinal plant are compared to their pharmacological activities ${ }^{5}$. Catharanthus roseus (L.) G. Don. (apocynaceae) is an evergreen herb native to Indian Ocean Island of Madagascar and common in many tropical and sub-tropical regions ${ }^{6}$. It has remarkable amounts of phenolic compounds and alkaloids. The anticancer alkaloids like vinblastine and vincristine are derived from stems and leaves. These alkaloids possess growth inhibition effect to some human tumours. The plant's ethanolic leaf extracts exhibit anti-diarrheal activity. Reduction in the serum levels of triglycerides, LDL-c, VLDLc and total cholesterol is observed with its leaf juice ${ }^{7}$. Another evergreen tree Alstonia scholaris (L.) R.br. of the same family is native to Indian sub - continent and South East Asia, especially rich in alkaloids ${ }^{8}$. The alkaloids alstonamine and rhazimanine present in its leaves exhibit antimalarial property ${ }^{9}$. Its leaf extracts are also used against congestion of liver, beri-beri, dropsy and ulcers ${ }^{10}$. Alstonia scholaris shows antibacterial activity in the crude methanolic extracts of the leaves. Antiasthmatic activity has been also reported in the ethanolic extracts of its leaves ${ }^{11}$. Currently, there is no study comparing these two described Apocynaceae family plants. The use of their leaf extract will not hamper the food industry, since their leaves are not edible. Thus, the effort has been carried out to examine whether variations are found in the phytochemical constituents of leaves of different categories of plants of the same family.

\section{MATERIALS AND METHODS}

\section{The Universe of study}

The research was carried out at Ravenshaw University, Cuttack, Odisha.

\section{Collection of plant materials}

Young green leaves of Catharanthus roseus and Alstonia scholaris were collected from the Department of Botany and Biotechnology garden, Ravenshaw University, Cuttack, Odisha (Figure 1 and 2). 


\section{Treatment of the collected plant materials}

The collected leaves of two plants were first rinsed with tap water then by distilled water thoroughly to take out all the dirt and air dried on brown paper in shade separately for 2-3 weeks (Figure 3 and 4). Leaves were properly dried followed by coarsely powdered, weighed and preserved in a sealed container for the experiments at room temperature (Figure 5).

\section{Experimental design for screening of phytochemicals in samples}

$7 \mathrm{~g}$ of powdered leaf samples of both Catharanthus roseus and Alstonia scholaris were separately dispensed in $100 \mathrm{ml}$ conical flasks (Borosil, India) containing $70 \mathrm{ml}$ each of distilled water, methanol and ethanol at a $40 \%(\mathrm{w} / \mathrm{v})$ concentration (Figure 6). The flasks were sealed with aluminium foil and were kept at a refrigerator at $4^{\circ} \mathrm{C}$ overnight to minimise the possibility of contamination. Then, the extracts were filtered through Whatman No.1 filter paper. Those filtrates were used for the screening of phytochemicals by methods used by Harborne $(1973)^{12}$. Dry yield was processed for further use in a refrigerator at $4^{\circ} \mathrm{C}$.

\section{Qualitative phytochemical analysis}

Qualitative analysis of phytochemicals like alkaloids (tannic acid test, mayer's test, wagner's test and hager's test), steroids (salkowski test and liebermann burchard test), proteins and amino acids (ninhydrin test, xanthoproteic test and biuret test) and carbohydrate (molisch's test, fehling's test), lipids and fats, vitamins, phenolic compounds, saponins, tannins, terpenoids, cardiac glycosides, flavonoids, anthraquinones, iridoids of leaf extracts were performed following the standard protocol of Harborne and Baxter (1993) ${ }^{13}$ and Bisht et al. $(2016)^{14}$.

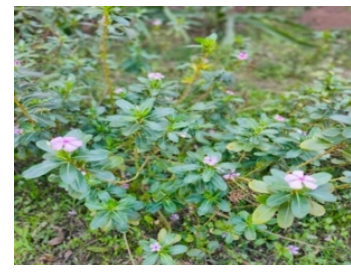

(a)

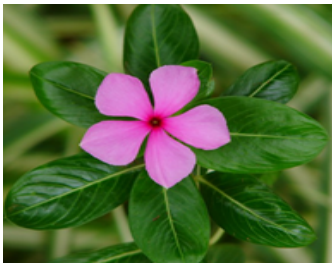

(b)

Figure 1: C. roseus (a) Plant and (b) Flower; photo: SP Mohanty, Ravenshaw University, Cuttack $\left(20.46^{0} \mathrm{~N}, \mathbf{8 5 . 8 9}^{\circ} \mathrm{E}\right)$

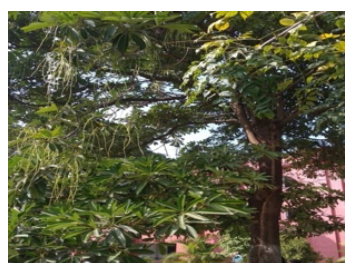

(a)

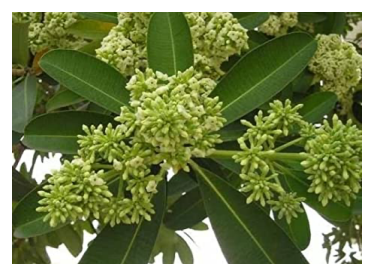

(b)

Figure 2: A. scholaris (a) Plant and (b) Flower; Photo: SP Mohanty, Ravenshaw University, Cuttack $\left(20.46^{0} \mathrm{~N}, 8^{85.89^{0}} \mathrm{E}\right)$

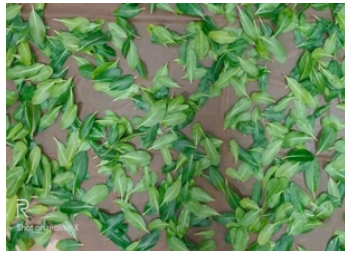

Figure 3: Leaves of $C$. roseus

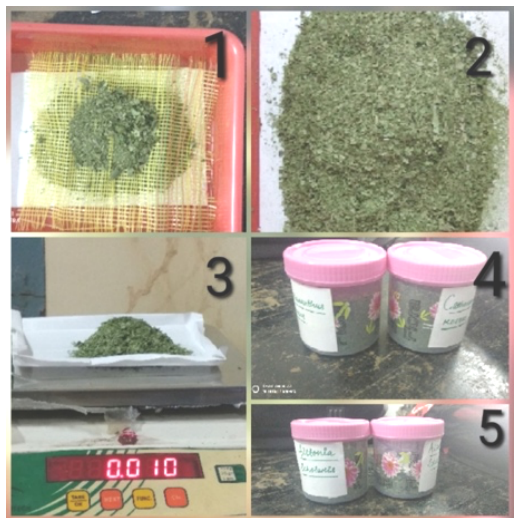

Figure 5: Step wise preparation of powder from the dried sample leaves

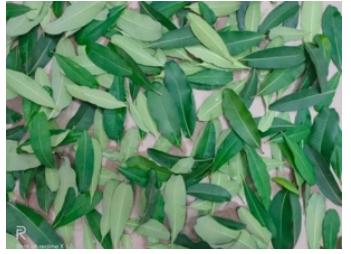

Figure 4: Leaves of $A$. Scholaris

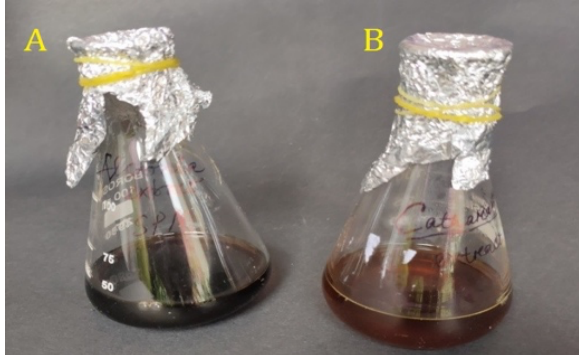

Figure 6: Aqueous leaf extracts of (A) A. scholaris and (B) C. roseus 
Table 1: Phytochemical screening of leaf extracts of $C$. roseus

\begin{tabular}{|c|c|c|c|}
\hline \multirow{2}{*}{$\begin{array}{c}\text { Phytochemicals } \\
\text { (Primary and Secondary Metabolites) }\end{array}$} & \multicolumn{3}{|c|}{ Solvents } \\
\hline & Aqueous & Methanol & Ethanol \\
\hline \multicolumn{4}{|c|}{$\begin{array}{ll} & \text { Alkaloids } \\
\end{array}$} \\
\hline Tannic Acid Test & $+\mathrm{ve}$ & $+\mathrm{ve}$ & $+\mathrm{ve}$ \\
\hline Mayer's Test & $+\mathrm{ve}$ & $+\mathrm{ve}$ & $+\mathrm{ve}$ \\
\hline Wagner's Test & -ve & $+\mathrm{ve}$ & -ve \\
\hline Hager's Test & -ve & -ve & -ve \\
\hline \multicolumn{4}{|c|}{ Steroids } \\
\hline Salkawski Test & $+\mathrm{ve}$ & -ve & -ve \\
\hline Liebermann burchard Test (By green approach) & $+\mathrm{ve}$ & -ve & $-\mathrm{ve}$ \\
\hline \multicolumn{4}{|c|}{ Proteins and Amino Acids } \\
\hline Ninhydrin Test & -ve & $+\mathrm{ve}$ & -ve \\
\hline Xanthoproteic Test & $+\mathrm{ve}$ & $+\mathrm{ve}$ & $+\mathrm{ve}$ \\
\hline Biuret Test & $+\mathrm{ve}$ & -ve & -ve \\
\hline \multicolumn{4}{|c|}{ Carbohydrates } \\
\hline Molisch's Test & $+\mathrm{ve}$ & -ve & -ve \\
\hline Fehling's Test & $+\mathrm{ve}$ & -ve & -ve \\
\hline Lipids and Fats & $+\mathrm{ve}$ & $+\mathrm{ve}$ & -ve \\
\hline Vitamins & $+\mathrm{ve}$ & -ve & -ve \\
\hline Phenolic Compounds & $+\mathrm{ve}$ & $+\mathrm{ve}$ & $+\mathrm{ve}$ \\
\hline Saponins & $+\mathrm{ve}$ & $+\mathrm{ve}$ & $+\mathrm{ve}$ \\
\hline Tannins & $+\mathrm{ve}$ & $+\mathrm{ve}$ & $+\mathrm{ve}$ \\
\hline Terpenoids & $+\mathrm{ve}$ & -ve & $+\mathrm{ve}$ \\
\hline Cardiac Glycosides & $+\mathrm{ve}$ & $+\mathrm{ve}$ & -ve \\
\hline Flavonoids & -ve & -ve & $+\mathrm{ve}$ \\
\hline Anthraquinones & -ve & -ve & -ve \\
\hline Iridoids & $+\mathrm{ve}$ & $+\mathrm{ve}$ & $+\mathrm{ve}$ \\
\hline
\end{tabular}

Table 2: Phytochemical screening of leaf extracts of $\boldsymbol{A}$. scholaris

\begin{tabular}{|c|c|c|c|}
\hline \multirow{2}{*}{$\begin{array}{c}\text { Phytochemicals } \\
\text { (Primary and Secondary Metabolites) }\end{array}$} & \multicolumn{2}{|c|}{ Solvents } & \multirow[b]{2}{*}{ Ethanol } \\
\hline & Aqueous & Methanol & \\
\hline \multicolumn{4}{|c|}{ Alkaloids } \\
\hline Tannic Acid Test & $+\mathrm{ve}$ & -ve & $+\mathrm{ve}$ \\
\hline Mayer's Test & -ve & $+\mathrm{ve}$ & $+\mathrm{ve}$ \\
\hline Wagner's Test & $+\mathrm{ve}$ & -ve & -ve \\
\hline Hager's Test & -ve & $+\mathrm{ve}$ & -ve \\
\hline \multicolumn{4}{|c|}{ Steroids } \\
\hline $\begin{array}{c}\text { Salkawski Test } \\
\end{array}$ & $+\mathrm{ve}$ & -ve & -ve \\
\hline Liebermann burchard Test (By green approach) & $+\mathrm{ve}$ & -ve & -ve \\
\hline \multicolumn{4}{|c|}{ Proteins and Amino Acids } \\
\hline Ninhydrin Test & -ve & -ve & -ve \\
\hline Xanthoproteic Test & $+\mathrm{ve}$ & $+\mathrm{ve}$ & $+\mathrm{ve}$ \\
\hline Biuret Test & -ve & -ve & -ve \\
\hline \multicolumn{4}{|c|}{ Carbohydrates } \\
\hline Molisch's Test & $+\mathrm{ve}$ & -ve & -ve \\
\hline Fehling's Test & $+\mathrm{ve}$ & + ve & -ve \\
\hline Lipids and Fats & -ve & $+\mathrm{ve}$ & -ve \\
\hline Vitamins & -ve & $+\mathrm{ve}$ & -ve \\
\hline Phenolic Compounds & $+\mathrm{ve}$ & $+\mathrm{ve}$ & $+\mathrm{ve}$ \\
\hline Saponins & + ve & $+\mathrm{ve}$ & $+\mathrm{ve}$ \\
\hline Tannins & $+\mathrm{ve}$ & $+\mathrm{ve}$ & + ve \\
\hline Terpenoids & $+\mathrm{ve}$ & -ve & $+\mathrm{ve}$ \\
\hline Cardiac Glycosides & $+\mathrm{ve}$ & -ve & -ve \\
\hline Flavonoids & -ve & $+\mathrm{ve}$ & $+\mathrm{ve}$ \\
\hline Anthraquinones & -ve & -ve & -ve \\
\hline Iridoids & $+\mathrm{ve}$ & $+\mathrm{ve}$ & $+\mathrm{ve}$ \\
\hline
\end{tabular}

\section{RESULT AND DISCUSSION}

Preliminary phytochemical screening of Catharanthus roseus leaves

The results of phytochemical analysis are presented in Table 1. The presence of alkaloids in all solvent extracts of experimental leaf samples was reported in this study, while lipids, fats, and cardiac glycosides were only found in aqueous and methanolextracts. In all extracts with the exception of methanol, terpenoids are observed. Of interest is the fact that only ethanol extract contains flavonoids and only aqueous extract contains steroids.
Vitamins are found in aqueous extracts exclusively. Anthraquinones are absent in the leaf extracts with all the three solvents.

Preliminary phytochemical screening of Alstonia scholaris leaves

The results of phytochemical analysis are presented in Table 2 . It indicated the presence of alkaloids, phenolic compounds, saponins, tannins and iridoids in all solvent extracts of experimental leaf sample. Proteins and flavonoids are found in methanol and ethanol extracts only where as lipids and fats are 
observed in aqueous and methanolic extract. Besides, terpenoids are observed in all extracts except methanol. Steroids, carbohydrates and cardiac glycosides are exclusively found in aqueous extracts and vitamins are found in methanolic extracts only. This screening gave negative results for the presence of anthraquinones in all the extracts tested.

\section{Comparative phytochemical analysis}

Among all the extracts using three different types of solvents, the aqueous extract of Catharanthus roseus possessed 12 types of phytochemicals while, the aqueous extracts of Alstonia scholaris showed the presence of 10 types of phytochemicals. So, aqueous extract is considered as the most appropriate solvent for the purpose. Both the plants contain significantly similar phytochemicals.

\section{CONCLUSION}

Being the members of same family, both these leaf extracts showed almost comparable presence of phytochemical constituents, which might support their use against several diseases. These are also valuable sources of materials like cosmetics, edible oils, gums, honey, etc. It also imitated optimism with respect to the development of many other nove chemotherapeutic agents or models from a plant that could be used to produce synthetically improved therapeutic agents in future.

\section{ACKNOWLEDGEMENT}

The authors are grateful to the Head, Department of Botany, Ravenshaw University, Cuttack, Odisha, India, for providing necessary guidance, encouragement and essential laboratory facilities. Our appreciation also goes to members of the laboratory, Ravenshaw University for their help.

\section{REFERENCES}

1. Ekalu A, Ayo RGO, James HD Hamisu I. A mini-review on the phytochemistry and biological activities of selected Apocynaceae plants, Journal of Herbmed Pharmacology 2019; Vol. 8(4): 269 - 273.

2. Iyamah, PC and Idu M. Ethnomedicinal survey of plants used in the treatment of malaria in Southern Nigeria, Journal of Ethnopharmacology 2015; Vol.173: 287-302.

3. Wadood A, Ghufran M, Jamal SB, Naeem M, Khan A and Ghaffar R. Phytochemical analysis of medicinal plants occurring in local area of Mardan. Biochemistry and Analytical Biochemistry 2013; Vol. 2(4): 1-4.
4. Saxena M, Saxena J, Nema R, Singh D and Gupta A. Phytochemistry of Medicinal Plants. Journal of Pharmacognosy and Phytochemistry 2013; Vol 1(6): 168182.

5. Shoba V, Ghosh K, Krishnapriya K and Elanchezhiyan C. Chemical composition and anti-mosquito potential of Catharanthus roseus leaves extract against larvae of Aedes aegypti. International Journal of Zoology and Applied Biosciences 2018; Vol. 3(2): 367-374.

6. Aruna MS, Prabha MS, Priya NS and Nadendla R. Catharanthus roseus: ornamental plant is now medicinal boutique. Journal of Drug Delivery and therapeutics 2015; Vol.5(3): 1-4.

7. Nisar A, Mamat AS, Hatim MI, Aslam MS and Syarhabil M. An updated review on Catharanthus roseus: phytochemical and pharmacological analysis. Indian Research Journal of Pharmacy and Science 2016; Vol. 3(2): 631-53.

8. Kaushik P, Kaushik D, Sharma N and Rana AC. Alstonia scholaris: It's Phytochemistry and pharmacology. Chronicles of young scientists 2011; Vol. 2(2): 71.

9. Khyade MS and Vaikos NP. Phytochemical and antibacterial properties of leaves of Alstonia scholaris R. Br. (Saptaparna). African Journal of Biotechnology 2009; Vol.8 (22): 64346436.

10. Misra CS, Pratyush K, Sagadevan LDM, James J, Veettil AKT and Thankamani V. A Comparative study on Phytochemical screening and antibacterial activity of roots of Alstonia scholaris with the roots, leaves and stem bark. International Journal of Research in Phytochemistry and Pharmacology 2011; Vol. 1(2): 77-82.

11. Pratap B, Chakraborthy GS and Mogha N. Complete aspects of Alstonia scholaris. International Journal of PharmTech Research 2013; Vol. 5(1): 17-26.

12. Harborne JB. Phytochemical Methods. Chapman and Hall Ltd., London; 1973. p. 49-188.

13. Harborne JB and Baxter H. Pyrrolizidine Alkaloids. In: Taylor, F., Ed., Phytochemical Dictionary, Bristol; 1993. p. 255-266.

14. Bisht R, Chanyal S and Agrawal PK. Antimicrobial and phytochemical analysis of leaf extract of medicinal fruit plants. Asian Journal of Pharmaceutical and Clinical Research 2016; Vol. 9(4): 131-136.

\section{Cite this article as:}

Srushti Prajna Mohanty et al. Comparative Phytochemical Screening of two valuable medicinal plants of family Apocynaceae (Catharanthus roseus (L.) G. Don. and Alstonia scholaris (L.) R.BR.). Int. J. Res. Ayurveda Pharm. 2021;12(2):42-45 http://dx.doi.org/10.7897/2277-4343.120243 every effort has been taken to verify the accuracy of the content published in our Journal. IJRAP cannot accept any responsibility or liability for the site content and articles published. The views expressed in articles by our contributing authors are not necessarily those of IJRAP editor or editorial board members. 